\title{
Reproductive activity and morphometric assessment of three commercial species of sea cucumber (Echinodermata) from Karimunjawa National Park, Indonesia
}

\author{
MUSTAGFIRIN $^{1,2, \boldsymbol{v}}$, DIAH PERMATA WIJAYANTI ${ }^{2}$, SUBAGIYO ${ }^{2}$ \\ ${ }^{1}$ Program in Marine Science, Department of Marine Science, Faculty of Fisheries and Marine Science, Universitas Diponegoro. Jl. Prof. H. Soedarto, \\ S.H., Kampus Tembalang, Semarang 50275, Central Java, Indonesia. Tel./fax.: +62-24-7474698, "email: mustagfirin150895@gmail.com. \\ ${ }^{2}$ Department of Marine Science, Faculty of Fisheries and Marine Science, Universitas Diponegoro. Jl. Prof. H. Soedarto, S.H., Tembalang, Semarang \\ 50275, Central Java, Indonesia
}

Manuscript received: 19 May 2021. Revision accepted: 20 July 2021

\begin{abstract}
Mustagfirin, Wijayanti DP, Subagiyo. 2021. Reproductive activity and morphometric assessment of three commercial species of sea cucumber (Echinodermata) from Karimunjawa National Park, Indonesia. Biodiversitas 22: 3333-3341. Sea cucumbers are benthic animals that have economic value and play an important role in the environment. Exploitation on large scale to fulfill high market demand, caused overexploitation. The number of sea cucumbers in Karimunjawa decreased as a result of limited management. There is no study conducted on the commercial sea cucumbers (Holothuria edulis, Pearsonothuria graeffei, and Bohadschia vitensis) in Nyamuk Island, Karimunjawa. The objectives of the research were to determine the morphometric assessment and the reproductive cycle of the three species. The morphometric assessment of weight showed that the weight of $H$. edulis ranges $247.3-2539 \mathrm{~g}, P$. graeffei 415.3-428.1g, and B. vitiensis 672.4-678.1g, respectively. The first maturity size of gutted body weight (GWB 50$)$ for $H$. edulis was $127.84 \mathrm{~g}$, P. graeffei $357.61 \mathrm{~g}$, and B. vitiensis $279.34 \mathrm{~g}$. The gonad somatic index (GSI) range 13.60-15.60\% for H. edulis, $14.75-12.25 \%$ for $P$. graeffei and $10.83-14.57 \%$ for B. vitiensis. The result of gonad somatic index with a value above $10 \%$ means that it has entered the spawning phase. The above data indicated that the three commercial species spawned monthly, during new moon. It is likely that the spawning peak occurred when the temperature was increased. However, the pattern of reproductive activity in this study was limited at Nyamuk Island. Future studies are needed to observe whether there is a correlation between the increasing water temperature and the reproductive activity of the three sea cucumbers.
\end{abstract}

Keywords: Bohadscia vitiensis, commercial sea cucumber, Holothuria edulis, morphometry, Pearsonothuria graeffei, reproductive activity

\section{INTRODUCTION}

Holothurians are known as sea cucumber worldwide, bêche de-mer in France, namako in Japan, plingkao in Thailand, and haishen in China, while in Indonesia common known as teripang, gamat, or gamet (Pangkey et al. 2012). In terms of ecology, sea cucumbers are marine organisms that have a vital ecological function in coral reef ecosystems (Conand 2008; Purcell et al. 2016; Buccheri et al. 2019). The sea cucumber is known to reduce the impact of ocean acidification and help the production of calcium carbonate deposits, by releasing ammonia as a byproduct of the digestive process (Schneider et al. 2011). Sea cucumber could recycle the nutrient by eating sediment consisting of organic matter and making nutrients at the bottom of the water through the feeding process (Uthicke 2001). Previous research from Wolkenhauer et al. (2010) shows that sea cucumbers play bioturbation benthic activity by filtering bottom sediment as a bioremediation. According to Purcell et al. (2016) sea cucumbers support enriching the ecosystem.

Sea cucumbers are one of the most potential export commodities in Indonesia (Choo 2008; Pangkey et al. 2012). The increasing demand from the market has led to the rapid exploitation of sea cucumbers (Sulardiono 2016;
Husain et al. 2017). The exploitation efforts had a significant impact on the decline of the populations of sea cucumbers (Hasan 2019). However, the related parties (stakeholders and government in the fisheries sector in Indonesia) have not given much attention to sea cucumber resources which have a low price (Husain et al. 2017).

Karimunjawa National Park (KNP) is known to have various species of sea cucumbers (Sulardiono 2011), some of those are commercial species (Mustagfirin and Hartati 2017). Commercial sea cucumbers most commonly found in KNP are Holothuria edulis, Pearsonothuria graeffei, Bohadschia vitiensis, and Stichopus vastus (Sulardiono 2016). These sea cucumbers may be located mainly in complex reef habitats (Conand et al. 2010; Sulardiono and Hendrarto 2014). These commercial sea cucumbers usually live at a depth of 0 to $10 \mathrm{~m}$ (Dissanayake and Stefansson 2012). Fishermen usually catch the sea cucumbers by handpicking using a traditional compressor as an apparatus in diving or called Traditional SCUBA (Mustagfirin 2020, unpublished data).

Nyamuk Island, one island of the KNP, is home to many commercial sea cucumbers (Mustagfirin and Hartati 2017). For example, every year around $1,478 \mathrm{~kg}$ of various dried sea cucumbers were traded from the island (Mustagfirin 2020, pers. com). However, there is currently 
no specific management of sea cucumber fishery in Karimunjawa including at Nyamuk Island. Moreover, although many species are traded, there are little data on the reproductive biology of the sea cucumber. The research about sea cucumber is limited to gonad studies, asexual modes such as fission, and how to cultivate the species (Sulardiono 2011). There is almost no information on reproductive activity and the morphometry of the commercial species. Therefore, it is necessary to conduct a study on the reproductive biology of the commercial sea cucumber species at Nyamuk Island as the important to manage the species in the future.

Many environmental factors are notion to have an effect on the reproductive activity in holothuroid (Hartati and Yanti 2006). For example, observation in laboratory experiments showed the influence of water temperature manipulation on sea cucumber Holothuria atra spawning (Yudiati et al. 2001). The moon cycle also affects the spawning time of some species (Mackey and Hentschel 2001; Ramofafia et al. 2001). H. vagabunda was reported to spawn during new moon at Jepara Waters, Central Java (Hartati and Yanti, 2006) while H. scabra spawning was observed during full moon at Langgur, Southeast Maluku (Rahantoknam 2017).

Here, we investigate the reproductive activity of the three commercial species under the influence of moon cycle, by observing the gonad somatic index (GSI) of the species and we analyze the morphometry, sex ratio, size, and weight at first maturity. Sea surface temperature was also recorded as one possible environmental trigger to observe whether or not it has influence in sea cucumbers spawning, at least at Nyamuk Island, Karimunjawa National Park, Central Java, Indonesia.

\section{MATERIALS AND METHODS}

\section{Study area}

The research was conducted during SeptemberNovember 2020, and samples were collected based on the moon cycle (first quarter, full, third quarter, and new moon). Samples were collected at Nyamuk Island waters, Karimunjawa National Park, Central Java, Indonesia. The map is presented in Figure 1.

\section{Procedures \\ Sample collection}

A total of 250 individuals of each species namely $H$. edulis, P. graeffei, and B. vitiensis were obtained from the compressor divers (traditional fisherman). The three species are quite abundant with number of catching in 2017 reaching 88,000 individuals based on (Mustagfirin 2020, unpublished data). The researchers in this study took samples (750 sea cucumbers) or $0.84 \%$ of the total sea cucumbers based on data in 2017 and explaining that the three species are not locally rare. The divers collected the samples at night with underwater lights. Collection was done every day for three months (September-November) and following the moon phase through 2 cycles (first quarter, full, third quarter, and new moon). Number of samples taken following a certain moon phase is presented in Table 1. The sample was then measured of its morphometry and reproductive activity. Each individual was dissected to identify the sex and to determine the stage of the gonad. The reproductive activity was determined by classifying the stage of gonad maturity of each sample of the species following (Conand 1981). The samples were used in morphometric measurements and reproductive activity was the same. The rest of samples were reared in bucket of water alive ( 4 hours after being first captured) until the measurement process was carried out.

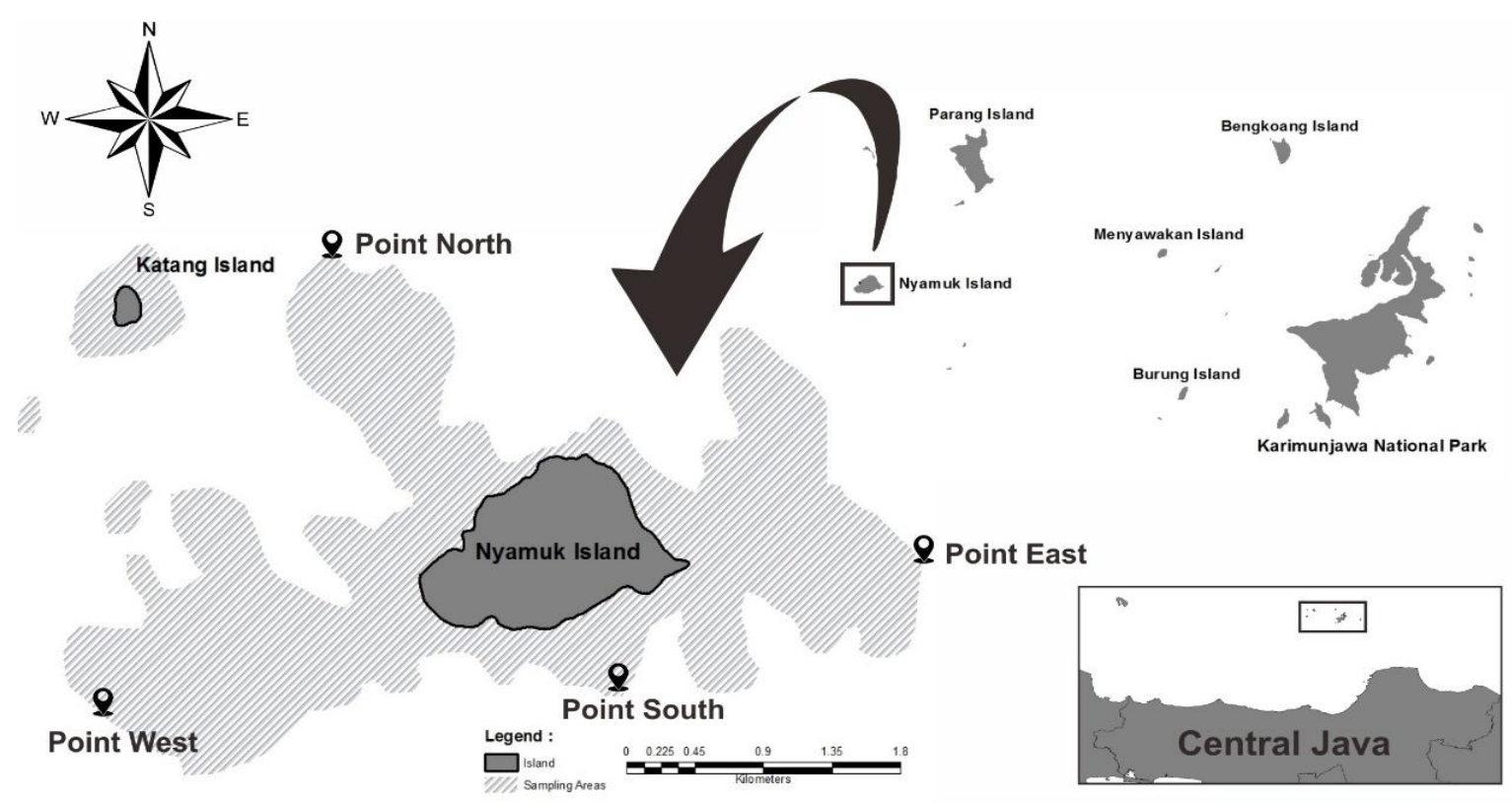

Figure 1. Study sites in Nyamuk Island waters, Karimunjawa National Park, Central Java, Indonesia and the study location of each

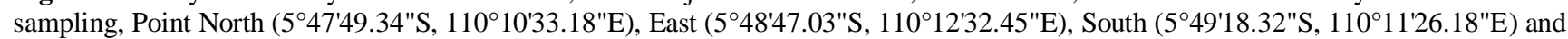
West (5॰49'18.99"S, 1109'35.51"E) 
Table 1. Samples of sea cucumbers of the study

\begin{tabular}{lcccccc}
\hline \multirow{2}{*}{ Moon cycle } & \multicolumn{3}{c}{ Moon cycle 1 (Sep-Oct) } & \multicolumn{3}{c}{ Moon cycle 2 (Oct-Nov) } \\
\cline { 2 - 7 } & H. edulis & $\boldsymbol{P .}$ graeffei & B. vitiensis & H. edulis & P. graeffei & B. vitiensis \\
\hline First quarter & 35 & 35 & 35 & 35 & 35 & 35 \\
Full moon & 35 & 35 & 35 & 40 & 40 & 40 \\
Third-quarter & 30 & 30 & 30 & 30 & 30 & 30 \\
New moon & 25 & 25 & 25 & 20 & 20 & 20 \\
Total & 125 & 125 & 125 & 125 & 125 & 125 \\
\hline
\end{tabular}

\section{Morphometric assessment}

The following parameters were measured (based on wet) total length (TL), gross weight (GSW), total width (TW), cuvierian weight $(\mathrm{CW})$, respiration tree weight (RTW), feces weight (FW), and the gutted body weight (GBW). The (TL) and (TW) of sea cucumber were measured by using measure picture application to ensure level of object accuracy using camera (Hartati et al. 2019). This study used application measurement considering that sea cucumbers are elastic, releasing water, and easily deformed (Purcell et al. 2009). Each individual gonad weight $(\mathrm{GW})$ was weighed using an electronic scale. The ventral part of each animal was excised and the entire gonad was removed. The others part of sea cucumber including the cuvierian tubule, respiration tree, feces, and were weighed using electronic scales and measured to the nearest $0.01 \mathrm{~g}$. The calculated part of sea cucumber will be used to determine the size of the first maturity, and number of individuals used to determine the sex ratio of the sea cucumber population on Nyamuk Island.

\section{Reproduction activity}

Males and females were identified by gonad morphology and color (Conand 1981). Reproductive individuals for three species were classified into five stages of sexual development following the criteria of Mustofa (2014): recovery (I), growth (II), maturity (III), partly spawned (IV), and spawned (V). The reproductive cycle of the sea cucumbers was compared with the lunar cycle and monthly average water temperature.

\section{Water Temperature assessment}

Measurement of water temperature $\left({ }^{\circ} \mathrm{C}\right)$ was carried out at the sampling location at night by using WQC (water quality checker) tools at depth of 3 meters below sea level. Measurement of water temperatures is carried out following the peak moon phase in each phase with three replicates. The results obtained were tabulated and used to compare the temperature parameter conditions with the reproductive activity of sea cucumbers.

\section{Data analysis}

Gonad somatic index

The gonad index was calculated using the ratio between the gonad weight $(\mathrm{GW})$ and the GBW through the formula (Asha and Muthiah 2008):

$$
G S I=\frac{G W}{G B W} x 100 \%
$$

\section{Size and weight at first maturity}

First sexual maturity was defined as the gutted body weight $\left(\mathrm{GBW}_{50}\right)$ and determination by using modification method Spearman-Karber (Udupa 1986), and the Total size $\left(\mathrm{TL}_{50}\right)$, width $\left(\mathrm{TW}_{50}\right)$ or $\left(\mathrm{GWS}_{50}\right)$, which the gonads of each individual were mature. It was determined by plotting the relationship between the percentage of individuals with mature gonads and their size or (GBW) classes (Conand 1981). Other measurement sex ratio of sea cucumber in the analysis by using chi-square analysis of the end.

\section{RESULTS AND DISCUSSION}

\section{Morphometric assessment}

Morphometric assessment of each species H. edulis, $P$. graeffei, and B. vitiensis presented in (Table 2).

Table 2. Result of morphometric assessment (H. edulis, P. graeffei, and B. vitiensis) in Nyamuk Island, Karimunjawa National Park, Central Java, Indonesia

\begin{tabular}{|c|c|c|c|c|c|c|}
\hline \multirow{2}{*}{ Type of morphometric } & \multicolumn{2}{|c|}{ H. edulis } & \multicolumn{2}{|c|}{ P. graeffei } & \multicolumn{2}{|c|}{ B. vitiensis } \\
\hline & Male & Female & Male & Female & Male & Female \\
\hline $\begin{array}{r}\text { Total of species } \\
\end{array}$ & 93 & 157 & 92 & 158 & 83 & 167 \\
\hline Total Length (TL) $(\mathrm{cm})$ & 21.88 & 21.79 & 28.82 & 28.20 & 29.05 & 28.32 \\
\hline Total Width (TW) $(\mathrm{cm})$ & 3.67 & 3.52 & 6.31 & 6.42 & 10.79 & 10.38 \\
\hline Gross Weight (GSW) (grams) & 247.3 & 253.9 & 428.1 & 415.3 & 678.1 & 672.4 \\
\hline Gutted Body Weight (GBW) (grams) & 158.7 & 166.9 & 311.8 & 298.8 & 495,6 & 494 \\
\hline Respiration Tree Weight (RTW) (\%) & 7 & 7 & 7 & 8 & 13 & 13 \\
\hline Cuvierian Weight (CW) $(\%)$ & 4 & 3 & 6 & 6 & 6 & 6 \\
\hline Feces Weight (FW) $(\%)$ & 25 & 24 & 14 & 14 & 8 & 8 \\
\hline
\end{tabular}


Sex-ratio, weight and size at first maturity

The sex ratio showed $H$. edulis and $P$. graeffei (1:1.7) and $B$. vitiensis (1:2) with (chi-square test, $\chi 2=19.36$, $\mathrm{P}=0.02$ ). Total individual presented in (Table 3).

The size at first maturity of $H$. edulis $\left(\mathrm{GBW}_{50}\right)$ was $127.84 \mathrm{~g}$, while $\left(\mathrm{TL}_{50}\right)$, first maturity was $18.83 \mathrm{~cm}$, and $\left(\mathrm{GSW}_{50}\right)$ range was $217.33 \mathrm{~g}$ (Figure 2a). P. graeffei $\left(\mathrm{GBW}_{50}\right)$ range was $357.61 \mathrm{~g}$, while $\left(\mathrm{TL}_{50}\right)$ range was $28.59 \mathrm{~cm}$, and $\left(\mathrm{GSW}_{50}\right)$ range was $459.59 \mathrm{~g}$ (Figure 2.B). Sea cucumber of $B$. vitiensis $\left(\mathrm{GBW}_{50}\right)$ range was $279.34 \mathrm{~g}$, while $\left(\mathrm{TL}_{50}\right)$ range was $32.74 \mathrm{~cm}$, and $\left(\mathrm{GSW}_{50}\right)$ range was $460.82 \mathrm{~g}$ (Figure $2 \mathrm{c})$. Weight at first maturity $\left(\mathrm{GBW}_{50}\right)$ and average of male and female sea cucumber weight caught at Nyamuk Island, was presented in (Figure 2).

\section{Gonad somatic index}

The measurement of gonad somatic index of the three species of sea cucumbers and related to the moon cycle, showed that spawning peak occurred during new moon (Figure 3). H. edulis had the highest gonad somatic index value (males and females) in the new moon with a GSI value is $13.60 \%$ and $15.60 \%$ respectively, while the lowest (males and females) GSI occurred in the first quarter with a value of $0.06 \%$ and $0.22 \%$. Similar results were obtained from the gonad somatic index measurement of $P$. graeffei (males and females). The highest GSI value was found during new moon with $14.75 \%$ and $12.25 \%$ conceived the gonads. While the lowest value was found in the first quarter moon with GSI of $0.12 \%$ and $0.57 \%$. Other results showed similar from $B$. vitiensis (males and females), which had the highest GSI values of $10.83 \%$ and $14.57 \%$ in new moon. While the lowest (male and females) GSI value of $0.26 \%$ and $2.16 \%$ in the third quarter moon.

\section{Gonad maturity level}

Gonad index was used to observe the reproductive activity of sea cucumbers, where this method determines the trend of gonad maturity monthly or annually, to look at the pattern of reproductive activity of the three species in the research location. Gonad index of $H$. edulis (males and females) showed 37 individuals $(14.80 \%)$ had spawned, $P$. graeffei showed 38 individuals (15.20\%), showed spawned, and $B$. vitiensis showed 42 individuals (16.80\%) spawned (Figure 4). The percentage of males and females is presented in Table 3.

\section{Water temperatures parameters}

The water temperature in this study showed higher range $\left(31.87-32.27^{\circ} \mathrm{C}\right)$ at night when the spawning peak occurs during the new moon. Conversely, the GSI will be lower during the first quarter moon when the temperature decreased (Figure 5).
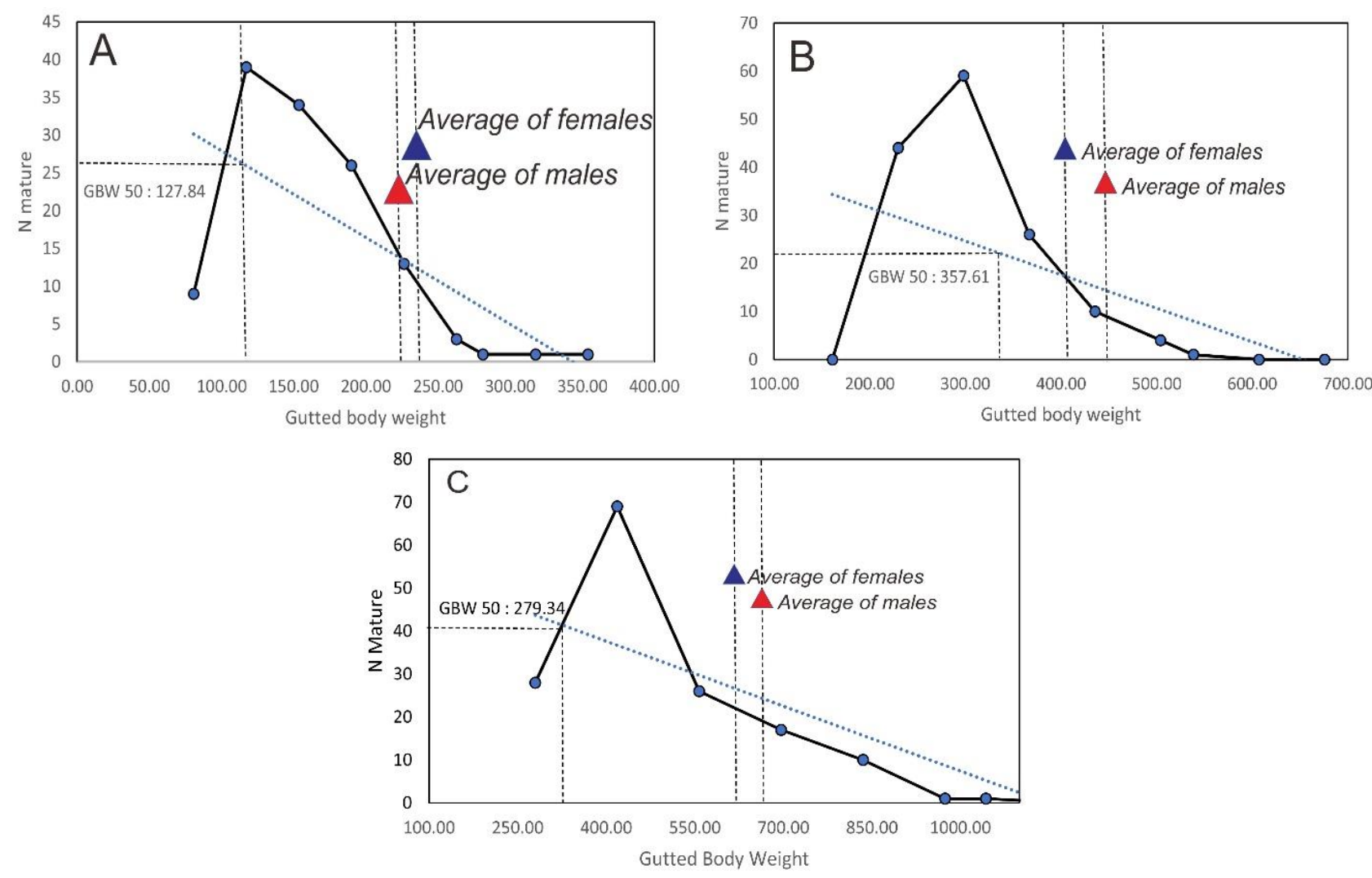

Figure 2. Result of gutted body weight at first maturity from each species (A. H. edulis; B. P. graeffei; and C. B. vitiensis) with average caught weight of sea cucumber fishery in Nyamuk Island, Karimunjawa National Park, Central Java, Indonesia 

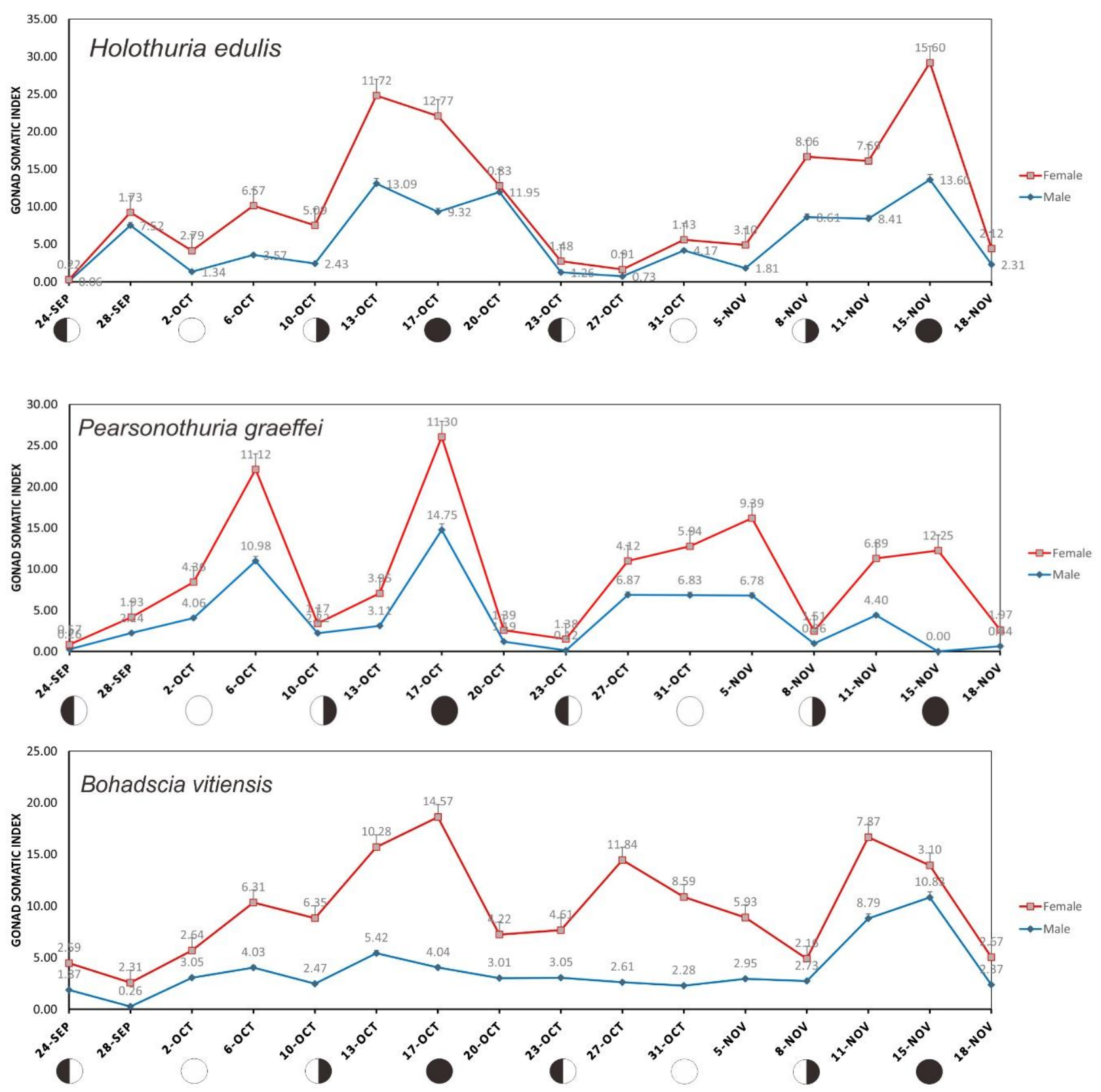

Figure 3. Result of reproductive activity by using GSI (gonad Somatic Index) from each species (H. edulis, P. graeffei, and B. vitiensis) compared with moon cycle in Nyamuk Island, Karimunjawa National Park, Central Java, Indonesia

Table 3. Result of total individual male and females gonad maturity during the study time

\begin{tabular}{lcccccc}
\hline \multirow{2}{*}{ Gonad Index } & \multicolumn{2}{c}{ H. edulis } & \multicolumn{2}{c}{ P. graeffei } & \multicolumn{2}{c}{ B. vitiensis } \\
\cline { 2 - 7 } & Males & Females & Males & Females & Males & Females \\
\hline Recovery (I) & 17 & 36 & 25 & 36 & 12 & 22 \\
Growth (II) & 26 & 44 & 15 & 29 & 21 & 42 \\
Maturity (III) & 18 & 30 & 22 & 40 & 19 & 38 \\
Partly spawned (IV) & 19 & 23 & 18 & 27 & 16 & 38 \\
Spawned (V) & 13 & 24 & 12 & 26 & 15 & 27 \\
Total & 93 & 157 & 92 & 158 & 83 & 167 \\
\hline
\end{tabular}



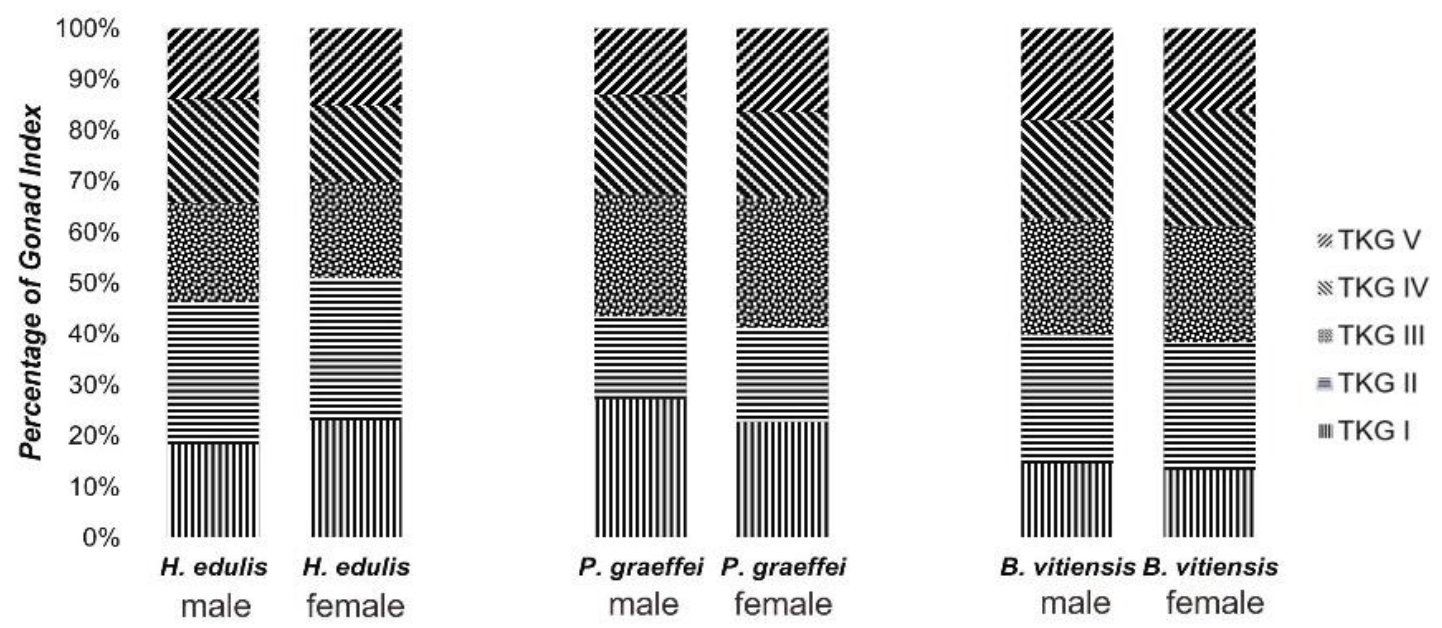

Figure 4. Percentage of gonad index (males and females) H. edulis, P. graeffei, and B. vitiensis during the study in Nyamuk Island, Karimunjawa National Park, Central Java, Indonesia

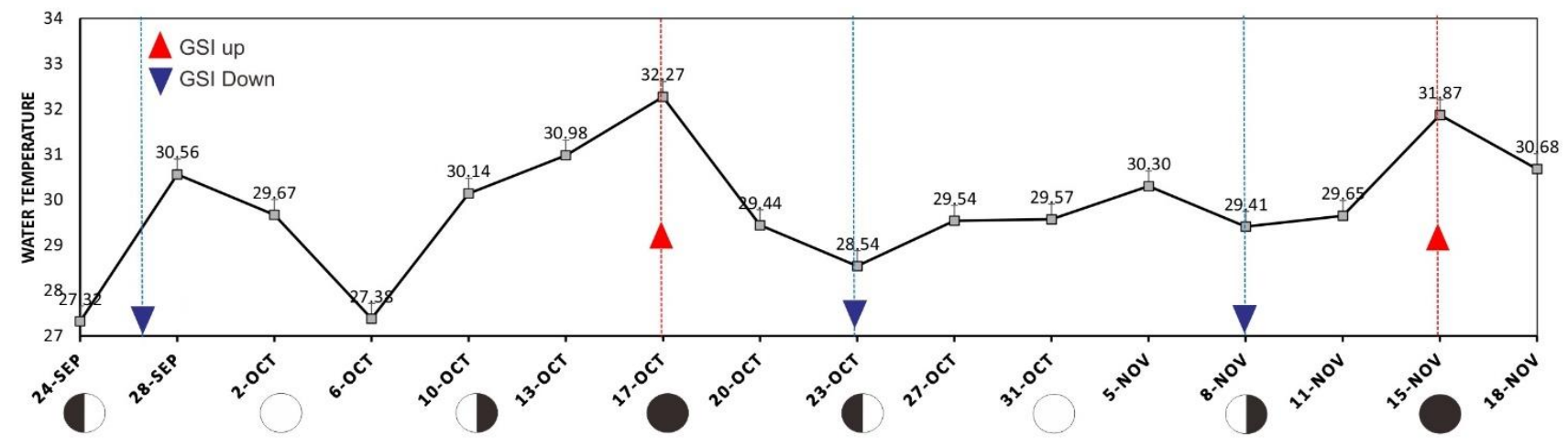

Figure 5. Result of average temperature (in-situ) in reproductive activity measurement, compared with gonad somatic index in Nyamuk Island, Karimunjawa National Park, Central Java, Indonesia. ( $\mathbf{\Delta}$ : mostly GSI up at the time, $\mathbf{\nabla}$ : Mostly GSI down at the time)

\section{Discussion}

The size at first maturity (Figure 2.A) from H. edulis based on gutted body weight $\left(\mathrm{GBW}_{50}\right)$ range was $127.84 \mathrm{~g}$. According to Navaro et al. (2012), this species had similar result with $H$. sanctori from Gran Canaria, Canarian Archipelago Spain with a range of $110 \mathrm{~g}$. The result of total length $\left(\mathrm{TL}_{50}\right)$ of $H$. edulis also showed similar result amount $17 \mathrm{~cm}$ and was comparable with $\mathrm{H}$. scabra by observation from (Kithakeni and Ndaro 2002). The result of gross weight $\left(\mathrm{GSW}_{50}\right)$ also showed that $H$. edulis had similar to $H$. sanctori at Gran Canaria, Canarian Archipelago with range of $200 \mathrm{~g}$ (Navaro et al. 2012). The results of $H$. edulis indicate that all the parameters in KNP are similar to another country, even have a slight different result.

The size at first maturity (Figure 2.B) from P. graeffei $\left(\mathrm{GBW}_{50}\right)$ was $357.61 \mathrm{~g}$, $\left(\mathrm{TL}_{50}\right) 28.59 \mathrm{~cm}$, and $\left(\mathrm{GSW}_{50}\right)$ $459.59 \mathrm{~g}$. This species was difficult to compare with other studies, because different parameters of weight or size were used and data was not always available (Kohler et al.
2009). The result of size at first maturity P. graeffei was presented in (Figure 2.B).

The size at first maturity (Figure 2c) of B. vitiensis $\left(\mathrm{TL}_{50}\right)$ was about $32.74 \mathrm{~cm}$. Omar et al. (2013) explained, similar results to the same species from Urghada, Red Sea, Egypt range $24.5-26.1 \mathrm{~cm}$. The size at first maturity is a common parameter used in almost all fisheries to set fishing limits (Navaro et al. 2012).

All the calculated parameters, along with gross weight $\left(\mathrm{GSW}_{50}\right)$ data from each species of $H$. edulis. P. graeffei, and $B$. vitiensis were compared with average caught assessment of sea cucumber fisheries in Nyamuk Island. The result showed that $\left(\mathrm{GSW}_{50}\right)$ value was lower than average caught of sea cucumber (morphometric assessment) (Table 2). The average size of $H$. edulis was higher $(247.3-253.9 \mathrm{~g})$ than $\left(\mathrm{GSW}_{50}\right)$ range $(217.33 \mathrm{~g})$. Sea cucumber $P$. graeffei with average $(415.3-428.1 \mathrm{~g})$ was lower than $\left(\mathrm{GSW}_{50}\right)$ range $(459.59 \mathrm{~g})$. Other species $B$. vitiensis with average (672.4-678g) was higher than $\left(\mathrm{GSW}_{50}\right)$ range $(460.82 \mathrm{~g})$. These results indicate that average caught (morphometric of weight) of sea cucumber 
in Nyamuk Island was above the average size (weight) of first maturity for $H$. edulis and $B$. vitiensis. Other results of average caught weight $P$. graeffe $i$ under the weight of first maturity, or there is sea cucumber fishing activity below the size in Nyamuk Island. Navaro et al (2012) explained that the size at first maturity was a relevant parameter for managing sea cucumber fishery and helps limit catch size. However, to effectively manage these resources, other parameters must also be studied further. That caused size at first maturity as indicator conservation is not enough to quantify sea cucumber fisheries activity (Navaro et al. 2012).

The sex ratio of $H$. edulis and $P$. graeffe $i$ was found as (female: male) with result from (1:1) throughout the sampling period. Moreover, the species from B. vitiensis showed a significant difference result as not $(1: 1)$ in this research. The result from $H$. edulis and $P$. graeffei, sex ratio usually precise with a balanced result (Dissanayake and Stefansson 2012; Omar et al. 2013). However, the result from some species of sea cucumber indicates a slightly unbalanced ratio with more females than males, or vice versa (Shiell and Uthicke 2005). This result from $B$. vitiensis showed unbalanced ratio. We assumed, those caused the capture of sea cucumbers in Nyamuk Island (KNP) was overexploitation in this species. The different ratios of individual sea cucumbers also indicated not only happened caused overexploitation. Gaudron et al (2008) explained that unbalanced ratio can also indicate optimal rate of reproduction from some species of sea cucumber. However, this statement needs justification from other research and more research especially about unbalanced sex ratio of sea cucumber in Nyamuk Island (KNP).

The result of Gonad Somatic Index of each species with value of more than $10 \%$ or stage $(\mathrm{V})$ can be interpreted as the peak of spawning activity of sea cucumber (Figure 3 ). The result showed that $H$. edulis had highest GSI around new moon. Hartati and Yanti (2006) reported that $H$. vagabunda in Jepara waters had the highest GSI in the new moon. Purwati and Luong (2003) showed that $H$. leucospilota also had high GSI and spawned in the new moon. Furthermore, Morgan (2000) reported that H. scabra showed the lunar spawning rhythm, which spawning occurred around new moon. P. graeffei demonstrated the same results as $H$. edulis, which spawned during new moon. Muthiga (2005) reported that $P$. graeffei spawn on the reef edge off Vabbinfaru Island North Male Atoll in the new moon. Another species, B. vitiensis showed the same result as $H$. edulis and $P$. graeffei, which spawned in the new moon. Desurmont (2008) also reported that species Stichopus herrmanni, experienced spawning in the new moon. Those observations indicated that those species had the same result of highest gonad maturity (GSI) occurred in the new moon in various sea waters in the world. Furthermore, it needs further research in various areas to prove this hypothesis.

Sea cucumbers showed an annual reproductive cycle (Conand 1993). Sea cucumber also showed continuous reproduction activity throughout the year (throughout Indonesia, including in this research location) (Darsono 1999). The peak of gonad somatic index (GSI) from $H$. edulis, P. graeffei, and B. vitiensis showed always happened in the new moon during October-November when water temperature tends to be warm. Mackey and Hentschel (2001) explained, that the lunar cycle is used by sea cucumber as a cue to initiate reproduction activity (e.g start the gonad maturation or spawning time). Others factor such us an environmental also affected the reproduction cycle of sea cucumbers (Ramofafia et al. 2003; Hartati and Yanti 2006). The results of this study also indicate that there was a correlation between the lunar cycle and the spawning events (Mercier et al. 2000). The spawning cycle observations from $H$. edulis $P$. graeffei, and B. vitiensis in this research, showed that those species could spawn every month throughout the year followed reference by (Sulardiono 2011). However, further studies should focus on the annual reproductive activity of these three commercial sea cucumber species in Karimunjawa National Park to confirm this statement.

The timing of reproduction activity from sea cucumber was reported to be determined by other proximate factors such as water temperature (Darsono 1999). In this research, H. edulis. P. graeffei, and B. vitiensis spawn in warm water conditions $\left(31.87-32.27^{\circ} \mathrm{C}\right)$. Navaro et al. (2012) explained that maximum reproductive activity was observed during warm months when the water conditions are warmer than usual. Despalotovic et al. (2004) also reported that $H$. tubulosa spawning occurs in warm seawater temperatures in the Adriatic Sea. Temperature stimulation research showed that temperature manipulation stimulated spawning of the sea cucumber up to (90\%) (Yudiati et al. 2001). The temperature of seawater seems to play a crucial role in reproductive activity. Understanding the effect of temperature on the spawning was important to predict and estimated spawning time of sea cucumbers in nature. However, further research is needed to obtain more robust data on the correlation between water temperature and spawning cycle in sea cucumber species.

In conclusion, the size at first maturity $\left(\mathrm{GBW}_{50}, \mathrm{TL}_{50}\right.$, and $\mathrm{GSW}_{50}$ ) of three commercial species of sea cucumber (H. edulis, P. graeffei, and B. vitiensis) showed similar results, respectively. These species from KNP was compared between other species and different place around the world and showed the same result on size at first maturity. These species had balanced sex ratio (H. edulis, $P$. graeffei) in the wild, while (B. vitiensis) with unbalanced sex ratio indicated cause overexploitation in KNP and other factors. The average catch assessment of sea cucumber fisheries in Nyamuk Island, was above the average size of first maturity for $H$. edulis and $B$. vitiensis, except $P$. graeffei. The gonad somatic index (GSI) indicated that these three commercial species of sea cucumber have spawn every month in the new moon around Sep-Oct in KNP. Others, when sea cucumber showed a reproductive activity in the wild, the seawater temperature in KNP was disposed of in warm water conditions. This condition indicated that seawater temperature might play a crucial role in reproduction activity of sea cucumbers. 


\section{ACKNOWLEDGEMENTS}

The authors thank Fabian Panji Ayodya (Diponegoro University, Indonesia) for discussions and for collecting data during the research. The facilities of Nyamuk Island Research Station part of Karimunjawa National Park are gratefully acknowledged. Thanks especially to Mashadi family who has provided logistical support, accommodation and also to Syarabilla for supporting as well.

\section{REFERENCES}

Asha PS, Muthiah P. 2008. Reproductive biology of the commercial sea cucumber Holothuria spinifera (Echinodermata: Holothuroidea) from Tuticorin, Tamil Nadu, India. Aquac Intl 16 (3): 231-242. DOI: 10.1007/s10499-007-9140-z

Buccheri E, Foellmer MW, Christensen BA, Langis P, Ritter S, Wolf E, Freeman AS. 2019. Variation in righting times of Holothuria atra, Stichopus chloronotus, and Holothuria edulis in response to increased seawater temperatures on Heron Reef in the Southern GBR. J Mar Sci. DOI: $10.1155 / 2019 / 6179705$.

Choo, P.S. 2008. Population status, fisheries and trade of sea cucumbers in Asia. In V. Toral-Granda, A. Lovatelli and M. Vasconcellos (eds). Sea cucumbers. A global review of fisheries and trade. FAO Fisheries and Aquaculture Technical Paper. No. 516. FAO, Rome.

Conand C. 1981. Sexual cycle of three commercially important holothurian species (Echinodermata) from the lagoon of New Caledonia. Bull Mar Sci 31 (3): 523-543.

Conand CL. 1993. Reproductive biology of the holothurians from the major communities of the New Caledonian Lagoon. Mar Biol 116: 439-450. DOI: 10.1007/BF00350061.

Conand C. 2008. Population status, fisheries and trade of sea cucumbers in Africa and Indian ocean 153-205. In: Toral-Granda V, Lovatelli A, Vasconcellos M. (eds.) Sea cucumbers. A global review on fishery and trade. FAO Fisheries Technical Paper. No. 516. FAO, Rome.

Conand C, Michonneau F, Paulay G, Bruggemann H. 2010. Diversity of the Holothuroid Fauna (Echinodermata) at La Réunion (Western Indian Ocean). West. Indian Ocean J Mar Sci 9 (2): 145-151.

Darsono P. 1999. Perkembangan pembenihan teripang pasir, Holothuria scabra Jaeger, di Indonesia. Oseana 24 (3): 35-45. [Indonesian]

Despalatovic M, Grubelic I, Simunovic A, Antolic B, Zuljevic A. 2004 Reproductive biology of the holothurian Holothuria tubulosa (Echinodermata) in the Adriatic Sea. J Mar Biol Assoc UK 84 (2): 409-414. DOI: 10.1017/S0025315404009361h.

Dissanayake DCT, Stefansson G. 2012. Habitat Preference of Sea Cucumbers: Holothuria atra and Holothuria edulis in the coastal waters of Sri Lanka. J Mar Biol Assoc UK 92 (3): 581-590. DOI: 10.1017/S0025315411000051.

Gaudron S M. Kohler S A. Conand, C. 2008. Reproduction of the sea cucumber Holothuria leucospilota in the Western Indian Ocean: biological and ecological aspects. Invertebr Reprod Dev 51 (1): 19-31. DOI: 10.1080/07924259.2008.9652253.

Hartati R, Yanti H. 2006. Kajian Gonad Teripang Getah (Holothuria vagabunda) pada Saat Bulan Penuh dan Bulan Baru di Perairan Bandengan, Jepara. Indon J Mar Sci 11 (3): 126-132. DOI: 10.14710/ik.ijms.11.3.126-132.

Hartati R, Zainuri M, Ambariyanto A, Redjeki S, Riniatsih I, Azizah R, Endrawati H. 2019. Aseksual Reproduction of Black sea cucumber from Jepara Waters. Indon J Mar Sci 24 (3): 121-126. DOI: 10.14710/ik.ijms.24.3.121-126.

Hasan, M. H. 2019. Destruction of sea cucumber populations due to overfishing at Abu Ghosoun area, Red Sea. J Basic Appl Zool 80 (1): 1-10. DOI: 10.1186/s41936-019-0074-6.

Husain G, Tamanampo JFWS, Manu GD. 2017. Community structure of sea cucumber (Holothuroidea) in the coastal area of the island of Jailolo, Subdistrict of Nyaregilaguramangofa, South Halmahera Regency, West of North Maluku. Jurnal Ilmiah Platax 5 (2): 177-188.

Kithakeni T, Ndaro SG. 2002. Some aspects of sea cucumber, Holothuria scabra (Jaeger, 1935), along the coast of Dar es Salaam. West. Indian Ocean J Mar Sci 1 (2): 163-168.
Kohler S, Gaudron SM, Conand C. 2009. Reproductive biology of Actinopyga echinites and other sea cucumbers from La Reunion (Western Indian Ocean): Implications for fishery management. West Indian Ocean J Mar Sci 8 (1): 97-111. DOI: 10.4314/wiojms.v8i1.56679.

Mackey A, Hentschel B. 2001. Factors that influence the reproduction of sea cucumbers. San Diego State University, San Diego.

Mercier A, Battaglene SC, Hamel, JF. 2000. Periodic movement, recruitment and size-related distribution of the sea cucumber Holothuria scabra in Solomon Islands. Hydrobiologia 440: 81-100. DOI: 10.1007/978-94-017-1982-7_8.

Morgan AD. 2000. Induction of spawning in the sea cucumber Holothuria scabra (Echinodermata: Holothuroidea). J. World Aquac Soc 31 (2): 186-194. DOI: 10.1111/j.1749-7345.2000.tb00352.x.

Mustagfirin dan R. Hartati. 2016. Keanekaragaman Sumber Daya Teripang Di Perairan Pulau Nyamuk, Kepulauan Karimunjawa. Prosiding: Seminar Tahunan Penelitian Perikanan dan Kelautan VI Universitas Diponegoro, Semarang 12 November 2016. [Indonesian]

Mustofa A. 2014). Frekuensi kematangan gonad teripang (Holothuroidea) di Pantai Bandengan Kabupaten Jepara. Jurnal Disprotek 5 (1): 11-54. [Indonesian]

Mezali K, Soualili DL, Neghli L. Conand C. 2014. Reproductive cycle of the sea cucumber Holothuria (Platyperona) sanctori (Holothuroidea: Echinodermata) in the southwestern Mediterranean Sea: interpopulation variability. Invertebr. Reprod Dev 58 (3): 179-189. DOI: $10.1080 / 07924259.2014 .883337$.

Muthiga N. 2005. Natural spawning observation of Pearsonothuria graeffei. SPC BechedeMer Inform Bull 27: 23-38.

Navarro GP, Sanz SG, Tuya F. 2012. Reproductive biology of the sea cucumber Holothuria sanctori (Echinodermata: Holothuroidea). Scientia Marna 76 (4): 743-752. DOI: 10.3989/scimar.03543.15B.

Omar HA, Razek FA, Rahman SA, El Shimy NA. 2013. Reproductive periodicity of sea cucumber Bohadschia vitiensis (Echinodermata: Holothuroidea) in Hurghada area, Red Sea, Egypt. Egypt J Aquat Res 39 (2): 115-123. DOI: 10.3989/scimar.03543.15B.

Pangkey H, Lantu S, Manuand L, Mokolensang J. 2012. Prospect of sea cucumber culture in Indonesia as potential food sources. J Coast Dev 15 (2): 114-124.

Purcell SW, Gossuin H, Agudo NS. 2009. Status and Management of the Sea Cucumber Fishery of La Grande Terre, New Caledonia. WorldFish Center Studies, Malaysia.

Purcell SW, Conand C, Uthicke S, Byrne M. 2016. Ecological roles of exploited sea cucumbers. Oceanogr Mar Biol 54: 386-367. DOI: $10.1201 / 9781315368597-8$.

Purwati P, Luong-van JT. 2003. Sexual reproduction in a fissiparous holothurian species, Holothuria leucospilota Clark 1920 (Echinodermata: Holothuroidea). Beche-de-Mer Inform Bull 18: 3338.

Rahantoknam SPT. 2017. Maturity gonad sea cucumber Holothuria scabra under the monthly cycle. IOP Conf Ser Earth Environ Sci 89: 012015. DOI: 10.1088/1755-1315/89/1/012015.

Ramofafia C, Byrne M, Battaglene S. 2001. Reproductive biology of the intertidal sea cucumber Actinopyga mauritiana in the Solomon Islands. J Mar Biol Assoc UK 81 (3): 523-531. DOI: 10.1017/S0025315401004179.

Ramofafia C, Byrne M, Battaglene C. 2003. Reproduction of the commercial sea cucumber Holothuria scabra (Echinodermata: Holothuroidea) in the Solomon Islands. Mar Biol 142 (2): 281-288. DOI: 10.1007/s00227-002-0947-x.

Schneider K, Silverman J, Woolsey E, Eriksson H, Byrne M, Caldeira K. 2011. Potential influence of sea cucumbers on coral reef $\mathrm{CaCO}_{3}$ budget: a case study at One Tree Reef. Geophys Res Biogeosci 116: 1-6. DOI: 10.1029/2011JG001755.

Shiell GR, Uthicke S. 2005. Reproduction of the commercial sea cucumber Holothuria whitmaei [Holothuroidea: Aspidochirotida] in the Indian and Pacific Ocean regions of Australia. Mar Biol 148 (5): 973-986. DOI: 10.1007/s00227-005-0113-3.

Sulardiono B. 2011. Kematangan gonad teripang komersial Stichopus vastus (Holothuriidea: Stichopodidae) di Perairan Karimunjawa, Kabupaten Jepara, Jawa Tengah. Jurnal Saintek Perikanan 7 (1): 2431. [Indonesian]

Sulardiono B. 2016. Potensi Pemanfaatan Teripang (Holothurians) di Perairan Karimunjawa, Kabupaten Jepara, Provinsi Jawa. Buletin Oseanografi Marina 5 (1): 64-72. DOI: 10.14710/buloma.v5i1.11298. [Indonesian] 
Udupa KS. 1986. Statistical method of estimating the size at first maturity in fishes. Fishbyte 4 (2): 8-10.

Uthicke S. 2001. Interactions between sediment-feeders and microalgae on coral reefs: grazing losses versus production enhancement. Mar Ecol Prog Ser 210: 125-138. DOI: 10.3354/meps210125.

Wolkenhauer SM, Uthicke S, Burridge C, Skewes T, Pitcher R. 2010. The ecological role of Holothuria scabra (Echinodermata: Holothuroidea) within subtropical seagrass beds. J Mar Biol Assoc UK. 90: 215-223. DOI: $10.1017 /$ S0025315409990518.

Yudiati E, Hartati R, Suryono CA. 2001. Kejut Suhu dan Salinitas pada Spawning Teripang Hitam Holothuria edulis sebagai Upaya Peningkatan Stock Alami di Perairan Jepara. Universitas Diponegoro, Semarang. [Indonesian]. 